\title{
DEVELOPMENT OF CVD MULLITE COATINGS FOR SiC FIBERS
}

\author{
RECEIVEO \\ MAY 302000 \\ O STI
}

\author{
March 15, 2000 \\ Report Prepared by \\ Vinod K. Sarin and Sesha Varadarajan \\ Boston University \\ 15, St. Mary's Street \\ Boston, MA-02134 \\ under \\ ORNL/Sub/94-SS110/04
}

\author{
for \\ OAK RIDGE NATIONAL LABORATORY \\ Oak Ridge, TN 37831 \\ Managed by \\ LOACKEED MARTIN ENERGY RESEARCH CORP. \\ for the \\ U.S. Department of Energy \\ under contract DE-AC05-96OR22464
}




\section{DISCLAIMER}

This report was prepared as an account of work sponsored by an agency of the United States Government. Neither the United States Government nor any agency thereof, nor any of their employees, make any warranty, express or implied, or assumes any legal liability or responsibility for the accuracy, completeness, or usefulness of any information, apparatus, product, or process disclosed, or represents that its use would not infringe privately owned rights. Reference herein to any specific commercial product, process, or service by trade name, trademark, manufacturer, or otherwise does not necessarily constitute or imply its endorsement, recommendation, or favoring by the United States Government or any agency thereof. The views and opinions of authors expressed herein do not necessarily state or reflect those of the United States Government or any agency thereof. 


\section{DISCLAIMER}

Portions of this document may be illegible in electronic image products. Images are produced from the best available original document. 


\title{
DEVELOPMENT OF CVD MULLITE COATINGS FOR SiC FIBERS
}

\author{
March 15, 2000 \\ Research sponsored by the U.S.Department of Energy, \\ Office of Fossil Energy \\ Advanced Research and Technology Development Material Program \\ Report Prepared by \\ Vinod K. Sarin and Sesha Varadarajan \\ Boston University \\ 15, St. Mary's Street \\ Boston, MA-02134 \\ under \\ ORNL/Sub/94-SS110/04 \\ for \\ OAK RIDGE NATIONAL LABORATORY \\ Oak Ridge, TN 37831 \\ Managed by \\ LOACKEED MARTIN ENERGY RESEARCH CORP. \\ for the \\ U.S. Department of Energy \\ under contract DE-AC05-96OR22464
}




\section{CONTENTS}

Page No.

$\begin{array}{ll}\text { Abstract } & 1\end{array}$

1.0 Introduction 2

2.0 Experimental details 4

2.1 CVD process 4

2.2 Oxidation Testing 4

2.3 Cyclic Oxidation Testing 5

2.4 Corrosion Testing 5

2.5 Tensile Testing 5

3.0 Results and discussion $\quad 6$

3.1 Effect of system parameters 7

3.1.1 System pressure 7

3.1.2 Input gas velocity 8

3.1.3 Al/Si molar ratio 9

3.2 Structure of mullite coating 10

3.3 Oxidation Testing 10

3.4 Cyclic Oxidation 12

3.5 Hot Corrosion 12

3.6 Tensile Strength 14

4.0 Conclusions 14

5.0 Acknowledgements 15

6.0 References 15

Distribution lists 


\section{ABSTRACT}

A process for depositing CVD mullite coatings on SiC fibers for enhanced oxidation and corrosion, and/or act as an interfacial protective barrier has been developed. Process optimization via systematic investigation of system parameters yielded uniform crystalline mullite coatings on SiC fibers. Structural characterization has allowed for tailoring of coating structure and therefore properties. High temperature oxidation/corrosion testing of the optimized coatings has shown that the coatings remain adherent and protective for extended periods. However, preliminary tests of coated fibers showed considerable degradation in tensile strength.

Research sponsored by the U.S. Department of Energy, Fossil Energy Advanced Research and Technology Development Materials Program, DOE/FE AA 151010 , Work breakdown structure element BU-2. 


\subsection{INTRODUCTION}

Increased operating temperatures to achieve higher efficiencies in several industrial applications have generated the need for new structural materials for components such as hot gas filters, heat exchangers, and gas turbine combustion liners. Ceramic matrix composites like $\mathrm{SiC}_{\mathfrak{f}} / \mathrm{SiC}$ owing to their oxidation resistance and mechanical properties at elevated temperature have been identified as a leading candidate material for many such applications [1]. Currently the use of these composites is being limited due to fiber degradation at the fiber-matrix interface either during processing or subsequent high temperature service. In monolithic $\mathrm{SiC}$, the formation of a thin silica layer at moderate temperatures has been shown to reduce the rate of further oxidation [2]. However, the non-stoichiometric nature of commercially available $\mathrm{SiC}$ fibers modifies the rate of oxygen diffusion through the scale resulting in active oxidation and corrosion [3]. Thus the development of an interfacial coating to protect $\mathrm{SiC}$ fibers is critical for the utilization of ceramic composites for such applications. This presents a major technical challenge since the interlayer must be thermodynamically compatible with the fiber and matrix, control stresses and frictional forces within the composite, and be environmentally stable.

Carbon whether deposited on the fibers prior to consolidation [4] or formed during processing [5] is the most commonly used interlayer in ceramic composites. A highly oriented graphite layer has been found to perform well in Nicalon fiber reinforced $\mathrm{SiC}$ matrix composites, yielding exceptional mechanical properties via reduction in interfacial 
stresses [1]. However, the poor oxidation resistance of carbon over $400^{\circ} \mathrm{C}$ results in fiber degradation via attack of the carbon coating at the exposed fiber ends [6].

Several alternative coatings to overcome the deficiencies of carbon have been investigated. So far hexagonal BN coatings have shown the most promise. This is not surprising since mechanically $\mathrm{BN}$ behaves like carbon [6], but has significantly better oxidation resistance. However, the presence of inherent oxygen in these coatings decomposes the fibers leading to both loss of strength and oxidation resistance. Other potential coatings like $\mathrm{TaC}, \mathrm{ZrC}$ also suffer from similar oxygen contamination problems [7].

Mullite $\left(3 \mathrm{Al}_{2} \mathrm{O}_{3} \cdot 2 \mathrm{SiO}_{2}\right)$, due to its unique properties such as thermal expansion match with $\mathrm{SiC}$, oxidation resistance, elevated temperatures mechanical and compositional stability has been targeted as a candidate material [8-10]. However, attempts to deposit mullite coatings by various processing conditions have met with limited success [11]. Several of the techniques developed require a high temperature post-heat treatment to convert amorphous alumina-silica into crystalline mullite, which results in fiber decomposition and micro-porosity [12-13]. Plasma spray deposition of mullite as a corrosion barrier coating has been reported [14], but since the resultant coatings are thick, non-uniform, and contain pores, they are unsuitable as a interfacial coating. Additionally, grit blasting is used to enhance adherence which not only degrades strength but is unusable for fiber tows. To overcome these problems, a process to chemically vapor deposited mullite coatings has been developed and patented at 
Boston University [15]. In the present investigation this process is being modified to develop an oxidation resistant interfacial barrier coating for $\mathrm{SiC}$ fibers.

\subsection{EXPERIMENTAL DETAILS}

\subsection{CVD Process}

Commercially available, organo-metallic precursor derived SiC fibers, namely Nicalon, Hi-Nicalon and Tyranno were used as substrates. The organic sizing on the as-received fiber tows was removed by heating them in air at $375^{\circ} \mathrm{C}$ for 4 hours. A vertical hot walled reactor CVD unit was used to deposit the coatings. The fibers were gripped in clips and inserted into a $95 \mathrm{~mm}$ long coating tube (Fig.1). The diameter of the coating tube could be varied to get different gas flow velocities. An axial temperature gradient of about $8^{\circ}$ was maintained to partially overcome axial depletion. The effect of process parameters such as input gas velocity, system pressure, and partial pressure of metallic chlorides $\left(\mathrm{P}_{\mathrm{MCIX}}\right)$ was investigated at a fixed substrate temperature of $972 \pm 4^{\circ}$. The coated fibers were characterized using SEM and XRD.

\subsection{Oxidation Testing}

Oxidation tests were carried out in oxygen between $1000^{\circ} \mathrm{C}$ to $1300^{\circ} \mathrm{C}$ for 100 to $200 \mathrm{~h}$. The flow rate of oxygen was varied from $500 \mathrm{ccm}$ to $1000 \mathrm{ccm}$. Weight measurements were taken every 25 hours by interrupting the experiment. Since oxygen flow was maintained while the furnace ramped down at $4^{\circ} \mathrm{C} / \mathrm{min}$, the actual duration of the test was actually slightly longer then reported. The uncoated samples used in these tests were "desized" and subsequently heated in the CVD reactor to mimic coating 
conditions. This ensured that the oxidation results were not influenced by weight loss due to "desizing" or volatilization.

\subsection{Cyclic Oxidation Testing}

Cyclic oxidation testing was performed at $1000^{\circ} \mathrm{C}$ in a reciprocating furnace with a 1hour heating and 1-hour cooling cycle. An oxygen flow of $250 \mathrm{ccm}$ was maintained throughout the cycle. Samples reached the set temperature in about 10 minutes, while forced cooling with a fan resulted in the fibers cooling to $\sim 50^{\circ} \mathrm{C}$ in about 25 minutes. Weight measurements were made after 10,100 and 250 cycles.

\subsection{Corrosion Testing}

Coated and un-coated fibers were loaded with approximately $0.15 \mathrm{mg} / \mathrm{cm}^{2}$ of $\mathrm{Na}_{2} \mathrm{SO}_{4}$. Hot corrosion tests were performed on these fibers at $1100^{\circ} \mathrm{C}$ in a horizontal tube furnace and at an oxygen flow rate of $250 \mathrm{ccm}$. Weight measurements were made every 25 hours by interrupting the experiment. Entire fiber tows were used to facilitate handling for taking weight measurements. However, this created some problems, as it was not possible to coat all the fibers of the tow uniformly.

\subsection{Tensile Testing}

Dr. Edgar Lara Curzio of Oak Ridge National Laboratory performed some very preliminary single fiber tensile test on mullite coated $\mathrm{SiC}$ fibers. Individual fibers were picked up using cellophane tape and mounted on cardboard holders with epoxy. The cardboard was cut along the center, so as to transfer the applied load to the fiber, and 
pulled in tension. To account for variations in fiber diameter, an average of 25 fibers from each tow were tested.

\subsection{RESULTS AND DISCUSSION}

Initial CVD coating experiments yielded tows having several undesirable characteristics such as brittleness, bridging in fibers, and non-uniform coatings. For example, initial bridging of the fibers (Fig.2) resulted in brittleness of the tows and also prevented the inside of the tows from being coated. This phenomena was by radial depletion of the reactants as they flowed from the outside to the inside of the tow diameter. It was determined that by increasing gas flow velocity and thus reducing growth rate, bridging could be reduced or eliminated. Experimental results showed that at gas flow velocities above $600 \mathrm{~cm} / \mathrm{s}$ bridging was completely eliminated. Additionally it was observed that by increasing the gas flow velocities further into the $600-800 \mathrm{~cm} / \mathrm{s}$ regime, the problem of axial depletion was also alleviated and $\sim 85 \mathrm{~mm}$ long fiber tows could be uniformly coated.

Surface morphology and the cross-section of a typical mullite coating on Nicalon fibers is shown in Fig.3. The coatings were observed to be dense, uniform in thickness (about $1 \mu$ ) with a fine-grained equiaxed structure. X-ray diffraction studies confirmed that the only crystalline phase present was mullite (Fig.4). X-ray analysis of mullite coatings on fibers usually showed distinct $\{(\mathrm{abO})$ (ba0)\} type peaks, indicating a normal orthorhombic structure. However, coatings grown on monolithic SiC substrates were observed to be typically tetragonal in structure [16]. The difference is probably due to 
combination of factors. Firstly, compositional since the $\mathrm{Al} / \mathrm{Si}$ ratio measured on the surface of the coated fibers was found to be lower than that measured on coatings on monolithic SiC. As has been previously reported [17], mullite coatings have been found to show an increase in their $\mathrm{Al}_{2} \mathrm{O}_{3}$ content, which drives the structure to become tetragonal, with an increase in coating thickness. Since the fibers had significantly thinner coatings, this compositional/structural difference can in a way be attributed to coating thickness. Secondly, it has been established that the tetragonal structure formed on monolithic $\mathrm{SiC}$ is not stable. Thus, the orthorhombic structures formed on the fibers may in part be due to the lower growth rates $(0.66 \mu \mathrm{m} / \mathrm{hr}$ vs. $5 \mu \mathrm{m} / \mathrm{hr})$ used for fibers, giving more time for equilibrium (stable) structure to be formed during growth of the coating.

\subsection{Effect of System Parameters}

\subsubsection{System pressure}

The system pressure was varied from 25 torr to 122 torr keeping all other parameters constant. Tubes of different diameters were used to introduce the gas and maintain the same gas flow velocity over the substrate regardless of the system pressure. This resulted in a fixed residence time assuming that the gas velocity changed with a change in the tube cross-section. To minimize possible errors due to this assumption all coating thickness measurements (growth rate) were done at the midpoint of the sample. Achieving fixed residence time by varying the amounts of dilutant gas, was not investigated due to: 
i) Possible shift of the optimum deposition zone, higher or lower depending on whether the velocity increased or decreased.

ii) Different viscosity's of the dilutant gas when compared to the reactant mixture giving rise to different boundary layer profiles.

Growth rate was found to increase at an exponential rate with increasing pressure (Fig.5). A similar study performed on monolithic SiC substrates showed linear increase in growth rate followed by a decrease in growth rate due to depletion [18]. The difference in trends is probably due to the higher gas velocity used for deposition on the fiber tows, which effectively reduces depletion. The surface morphology of the coating obtained on fibers are shown in Fig.5. At 25 and 50 torr very fine nano-crystalline grains $(50-100 \mathrm{~nm})$ were observed on the surface. At 80 torr, the coatings had relatively equiaxed grains and were uniform in thickness. However at 125 torr, the coatings had varied surface morphology along the diameter of the tows and were non-uniform.

\subsubsection{Input gas velocity}

The linear gas flow velocity or rather the residence time of the gaseous species in the hot zone of the reactor was found to strongly influence homogenous gas phase nucleation and growth rate. Mullite coatings were grown for 75 minutes using different gas flow velocities while keeping all other parameters constant (Fig.6). It can be seen that growth rate has an even stronger exponential dependence on velocity than system pressure. The surface morphology showed a trend towards larger grain sizes with decrease in gas flow velocity, because of a lack of the effect of gas depletion. However, 
if the same tests were to be performed at a much lower average velocity, it is projected that the growth rate may not show such a strong dependence on the velocity, mainly due to depletion effects.

\subsubsection{Al/Si molar ratios}

The Al/Si molar ratio of the input gas was experimentally varied by i) holding the Al/Si ratio constant while changing the total partial pressure of metallic chlorides, and ii) holding the total partial pressure of metallic chlorides constant while changing the Al/Si ratio.

The effect of partial pressure of metallic chlorides (sum of the partial pressures of $\mathrm{AlCl}_{3}$ and $\mathrm{SiCl}_{4}$ ) on coating thickness for a fixed $\mathrm{Al} / \mathrm{Si}$ ratio of 3:1 was investigated in the 0.25 to 0.70 torr range (Fig.7). Typical fine-grained microstructures were observed in all the samples, while X-ray diffraction indicated no differences in crystallanity. The observed decrease in growth rate at partial pressures greater than 0.53 torr is probably due to increased gas phase nucleation and depletion.

The effect of varying $\mathrm{Al} / \mathrm{Si}$ ratios on growth rate, while keeping the partial pressure of metallic chlorides constant at 0.53 torr is shown Fig.8. The samples grown with input ratio of 2:1 and 3:1 showed conventional microstructures with the $3: 1$ surface morphology being slightly less "plate-like". The 4:1 samples showed different morphologies with the outside of the tow showing regions of cluster formation wherein the growth seemed to be occurring independently of the substrate, and the inside of the 
tow showing fine-grained microstructure. Although all the coatings were less than a micron thick and showed only mullite peaks in X-ray diffraction, the $\mathrm{Al} / \mathrm{Si}$ ratio measured at the surface of these coatings showed significant differences (Fig.9). TEM studies performed on monolithic SiC [16] have indicated that samples grown with lower Al/Si ratios have thicker (Si-rich) amorphous interfacial layers. It is possible that a similar effect might be contributing to this observed difference in Al/Si ratios on the surface of these coated fibers.

\subsection{Structure of Mullite Coating}

A schematic of the proposed structure of a mullite coating on SiC fibers is shown in Fig.10. Mullite coatings were observed to start as nano-crystallites on the amorphous interface and then transition to much larger "platelet-like" columnar grains. The thickness of the nano-crystalline zone was found to depend on the growth rate, with slower growth rates yielding thicker zones. The transition from nano-crystalline to columnar platelets is projected to be the result of preferential growth along certain crystalline directions on correctly oriented grains.

\subsection{Oxidation Testing}

Nicalon fibers are known to degrade at temperatures around $1000^{\circ} \mathrm{C}$ due to carbothermal degradation [19]. Although the reactions involved are not fully resolved, one set of reactions proposed [20] are that silicon-oxycarbide $\left(\mathrm{Si}_{3} \mathrm{C}_{4} \mathrm{O}\right)$ pyrolyses to form $\mathrm{SiO}$ gas;

$$
\mathrm{Si}_{3} \mathrm{C}_{4} \mathrm{O} \rightarrow \mathrm{SiO}(\mathrm{g})+2 \mathrm{C}+2 \mathrm{SiC}
$$


which reacts with free carbon to from $\mathrm{CO}$ gas;

$$
\mathrm{SiO}+2 \mathrm{C} \rightarrow \mathrm{CO}_{(\mathrm{g})}+\mathrm{SiC}
$$

so consequently the Nicalon fiber pyrolyzes to form $\mathrm{SiC}$ and $\mathrm{CO}$;

$$
\mathrm{Si}_{3} \mathrm{C}_{4} \mathrm{O} \rightarrow \mathrm{CO}_{(\mathrm{g})}+3 \mathrm{SiC}
$$

This results in significant weight loss due to volatilization. However, in the presence of oxygen $\mathrm{SiC}$ reacts to form $\mathrm{SiO}_{2}$ which contributes to weight gain;

$$
\mathrm{SiC}_{(\mathrm{s})}+1.5 \mathrm{O}_{2} \rightarrow \mathrm{SiO}_{2(\mathrm{~s})}+\mathrm{CO}_{(\mathrm{g})}
$$

Therefore during oxidation both mechanisms are at work and consequently the weight measured is the resultant of the two competing mechanisms. However, the dominant mechanism is that of silica formation [21].

All uncoated fibers developed silica scale (cristobalite) as confirmed by the significant weight gain observed during testing. Additionally, other surface defects such as pitting (due to volatilization of the fiber) and bubbled surfaces (due to $\mathrm{CO}$ and SiO entrapment in the silica layer) were also observed (Fig.11). On the other hand, mullite coatings yielded excellent protection to Nicalon fibers. SEM analysis of the coated fibers indicated no surface damage. Extensive cross-sectional examination showed undamaged interfaces, and no structural changes. Nonetheless, significant damage at the uncoated ends was observed in all cases (Fig.12).

Testing at $1000^{\circ} \mathrm{C}$ indicated that even though mullite coated samples provided protection, the uncoated samples themselves did not degrade significantly (Fig.13). 
However, when the samples were tested at $1300^{\circ} \mathrm{C}$ the superior performance of mullite coated Nicalon (Fig.14) and Hi-Nicalon (Fig.15) tows was evident.

\subsection{Cyclic Oxidation}

The inclusion of coated fibers in composites that are targeted for applications which are routinely subjected to thermal cycling, introduce further constraints such as i) thermal shock resistance of the protective coating, and ii) low thermal expansion mismatch between the coating and the fiber, to avoid spallation. Mullite coated fibers showed no spallation and negligible weight gain after 250 cycles at $1000^{\circ} \mathrm{C}$ (Fig.16). X-ray diffraction (Fig.17) indicated no structural changes in the coating. However, as has been reported [22], grain growth in the fibers was observed as confirmed by the sharpening of the $\beta$ SiC (111) peak at $35^{\circ}$.

\subsection{Hot Corrosion}

Alkali impurities (such as $\mathrm{Na}$ ) in fuel systems are a major concern due to hot corrosion degradation of SiC fibers [23]. The formation of a silica scale on the surface of SiC fibers has been discussed earlier. In the presence of $\mathrm{Na}_{2} \mathrm{SO}_{4}$ the following additional reactions are expected to occur:

$$
\begin{aligned}
& x \mathrm{SiO}_{2(\mathrm{~s})}+\mathrm{Na}_{2} \mathrm{SO}_{4(l)} \rightarrow \mathrm{Na}_{2} \mathrm{O} \cdot x \mathrm{SiO}_{2(l)}+\mathrm{SO}_{3} \\
& \mathrm{Na}_{2} \mathrm{SO}_{4(l)} \rightarrow \mathrm{Na}_{2} \mathrm{O}_{(\mathrm{s})}+\mathrm{SO}_{3(\mathrm{~g})} \\
& \mathrm{Na}_{2} \mathrm{O}_{(\mathrm{s})}+x \mathrm{SiO}_{2(\mathrm{~s})} \rightarrow \mathrm{Na}_{2} \mathrm{O} \cdot x \mathrm{SiO}_{2(l)}
\end{aligned}
$$


Thus in the presence of the $\mathrm{Na}_{2} \mathrm{SO}_{4}$ the protective silica scale is converted to a liquid which is no longer protective. Additionally, transport rates throughout the liquid are much higher contributing to increased rate of attack of the substrate.

In the case of SiC fibers the silica layer formed is simultaneously expected to react at the interface with the free carbon in the substrate [24] resulting in additional degradation as follows:

$$
\mathrm{SiO}_{2(\mathrm{~s})}+\mathrm{C}_{(\mathrm{s}))} \rightarrow \mathrm{SiO}_{(\mathrm{g})}+\mathrm{CO}_{(\mathrm{g})}
$$

Obviously this reaction is accompanied by a weight loss and the evolved gasses are expected to diffuse through the silica layer. Kim, et al. [24] have suggested that beyond a certain thickness of the silica layer the diffusion distances become too large and the gasses get trapped, reducing further degradation. However, it is projected that since the scale is expected to liquefy, it is not likely to trap any of the reaction gasses, and the degradation reaction will not be slowed down. This might partly explain the significant weight loss observed in the fibers (Fig.18).

Several distinct types of damage due to corrosion were observed in the uncoated fibers (Fig.19). In contrast the mullite coated samples showed very good protection. Figure 20 shows the cross section and surface of the coated fiber after the test. It can be seen that both the coating-fiber and coating-salt interfaces are clean. However, uncoated ends showed extensive damage. To a very limited degree $(<5 \%)$ some silica formation on the surface of the coated fiber was observed. It is not clear if this was due to nonuniform coating or occasional cracks obtained due to handling of the fibers. 


\subsection{Tensile Strength}

Preliminary single fiber tensile test showed strength drops, due to mullite coatings, that were alarming, especially since the coatings were typically found to be crack free. Average strength values for coated Nicalon were $11.9 \pm 3.7 \mathrm{gm}$, coated Hi-Nicalon were $17.7 \pm 5.6 \mathrm{gm}$, and both types of uncoated fibers were measured to be around $43.1 \pm$ $6.2 \mathrm{gm}$. The reason for this higher than expected degradation in strength needs to be investigated.

\subsection{CONCLUSION}

A modified CVD process to deposit crystalline mullite coatings on SiC fibers has been developed. Growth rate was found to have a exponential dependence on system pressure and input gas velocity. Coatings grown using partial pressure of metallic chlorides higher than 0.53 torr showed a decrease in growth rate due to depletion and gas phase nucleation. Structural investigation showed that plate-like columnar mullite grains develop out of nano-crystalline mullite zones that nucleate on amorphous interfacial layers. The thickness of the two zones was found to depend on the growth rate. Oxidation tests performed on mullite coated Nicalon and Hi-Nicalon fibers showed excellent protection up-to 200 hours at $1300^{\circ} \mathrm{C}$. The coatings also performed well in a cyclic oxidation test carried out for 250 cycles at $1000^{\circ} \mathrm{C}$ and a sodium sulfate hot corrosion test performed at $1200^{\circ} \mathrm{C}$. 


\subsection{ACKNOWLEDGEMENTS}

Research sponsored by the U.S. Departmenmt of Energy, Assistant Secretary for Energy Efficiency and Renewable Energy, Office of Transportation Technologies, as part of the Ceramic Technology Project of the Propulsion System Materials Program, and Fossil Energy AT\&TD Materials Program under contract numbers DE-AC05960R22464 with Lockheed Martin Energy Research Corp. The authors would like to acknowledge Arun K Pattanaik, Edgar Lara Curzio, Dave Stinton, and R. Lowden for their help.

\subsection{REFERENCES}

1. R. W. Goettler, S. Sambasivan, and V.Dravid, Creamic Eng. and Sci. Proc., 18 (3) 279 (1997).

2. N.S. Jacabson, J. Am. Ceram. Soc. 76 (1) (1993).

3. Parthasarthy, J. Am. Ceram. Soc., 78 (7) (1995).

4. R.A. Lowden, ORNLTTM-11039,March,1989.

5. R.A. Lowden, Ceramic Transactions, 19 619-630 (1991).

6. R.A. Lowden, Proc. of $12^{\text {th }}$ Annual Conf. on Fossil Energy Materials, 1998.

7. N.I. Baklanova, M.A. Korchagin, V.N. Kulyukin and N.Z. Lyakhov, J.Mat. Syn. and Proc., 6 (1) 15- 20 (1998).

8. L.A. Akshay, D.M. Dabba and M. Sarikaya, J. Am. Ceram. Soc., 74 (10) 2343 (1991).

9. P.F. Becher, J. Am. Ceram. Soc., 74 (2) 255 (1991)

10.S. Somiya and Y. Hirata, Am. Ceram. Soc. Bull, 70 (10) 1624 (1991).

11.J. Schienle and J. Smyth, Final Report, ORNL.Sub/84-47992/1 (1987). 
12. K. Okada and N. Otsuka in S.Somiya (ed.), American Ceramic Society, Ceramic Transactions, 6425 (1990).

13.O.R. Monteiro, Z.Wang and I.G. Brown, J. Mater. Res., 12 (9) 2401 (1997).

14. K.N. Lee, R.A. Miller and N.S. Jacabson, Advances in Ceramic -Matrix Composites, Ceramic Transactions, 38565 (1994).

15. V.K. Sarin and R.P. Mulpuri, U.S. Patent No. 5,763,008 (1998).

16.Ping Hou, S.N.Basu and V.K.Sarin, J.Mater.Res., 14 (7) 2952 (1999).

17.D. Dopalapudi, Masters Thesis, Boston University, 1996.

18. M.Auger, Ph.D thesis, Boston University, 1999.

19. M. Huger, S. Souchard and C. Gault, J. of Mat. Sci. Letters, 12 414-416 (1993).

20.T. Ishikawa, Composites Sc. and Tech., 51 135-144 (1994).

21. N.I. Baklanova, M.A. Korchagin, V.N. Kulyukin and N.Z. Lyakhov, J.Mat. Syn. and Proc., 5 (6) 425- 430 (1997).

22. C. Vahlas, P. Rocabois, C. Bernard, J. of Matr. sci.,.29 (22) 5839 (1994).

23.N. S. Jacabson and D.S. Fox, J. Am. Ceram. Soc.,79 (9) 2489 (1996).

24. Hyoun-Ee Kim and A.J. Moorhead, J. Am. Ceram. Soc. 74 (3) 666-669 (1991). 


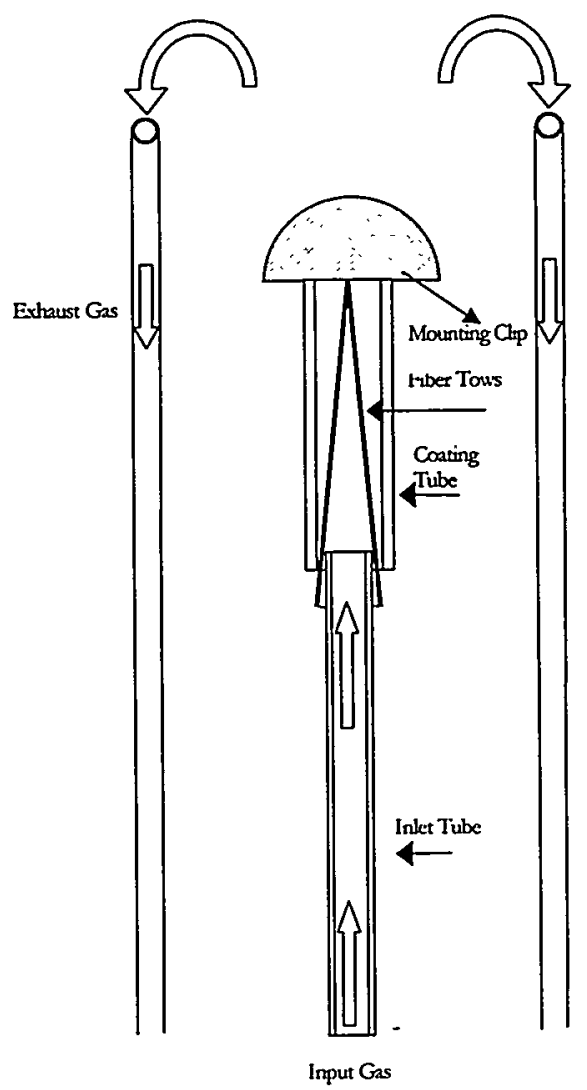

Figure 1: Schematic of fixture used to coat fiber tows.

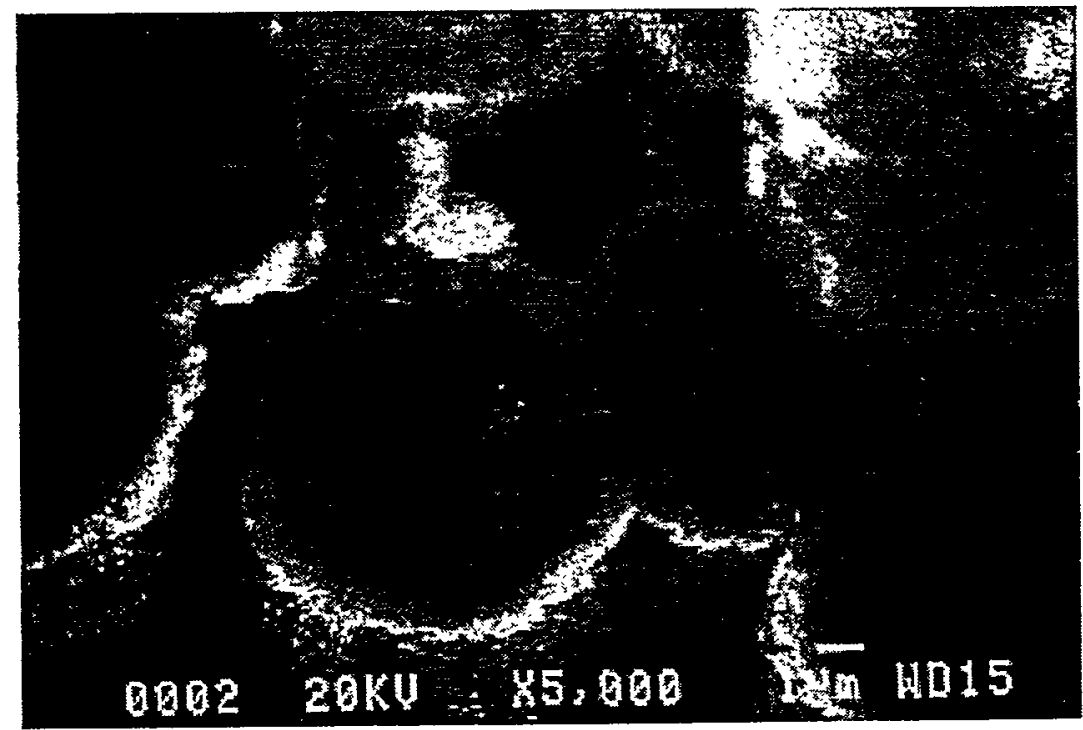

Figure 2: SEM micrograph showing bridging in SiC fiber tows. 

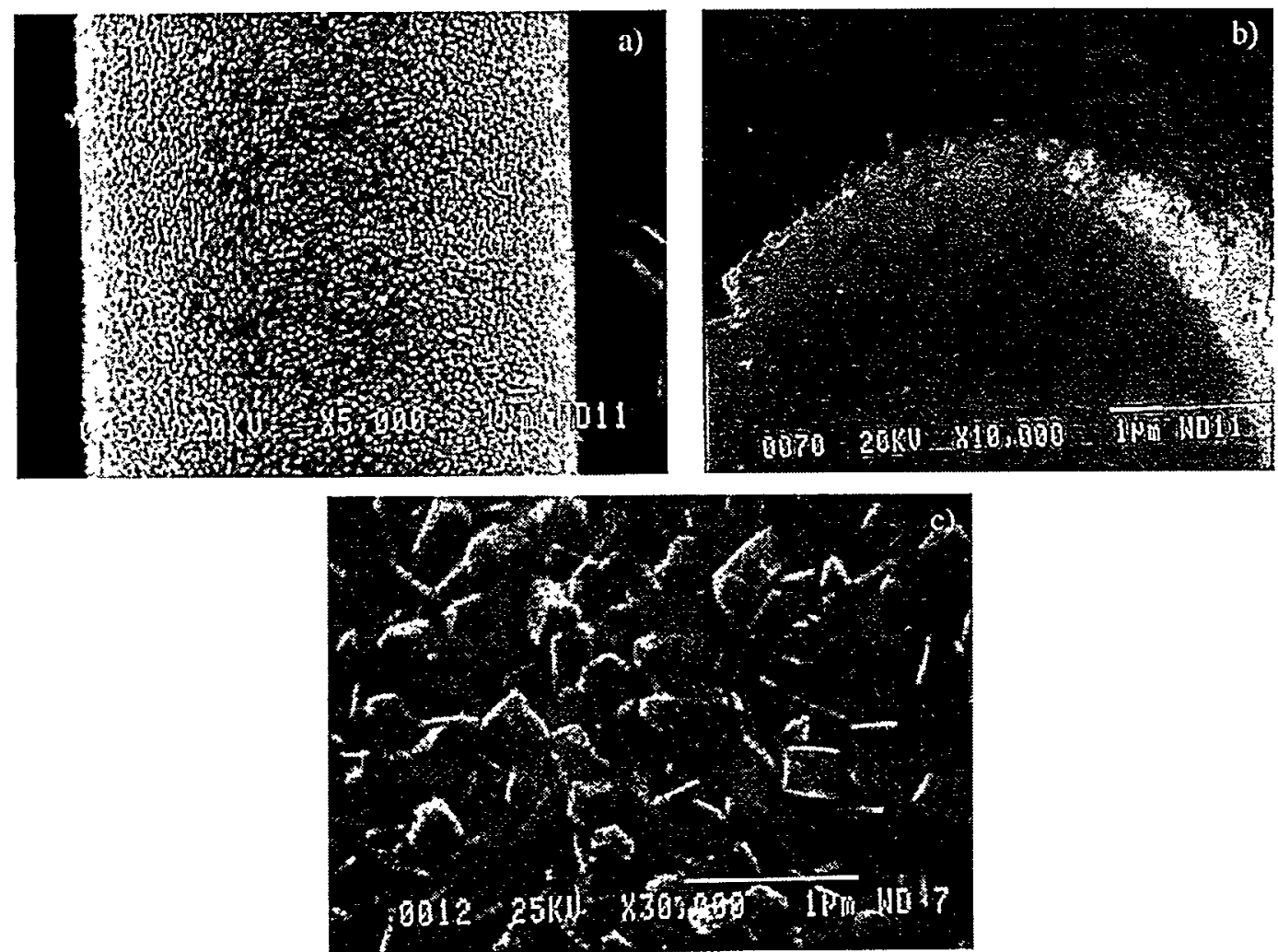

Figure 3: Micrographs showing mullite coated fiber, surface morphology and cross-section.

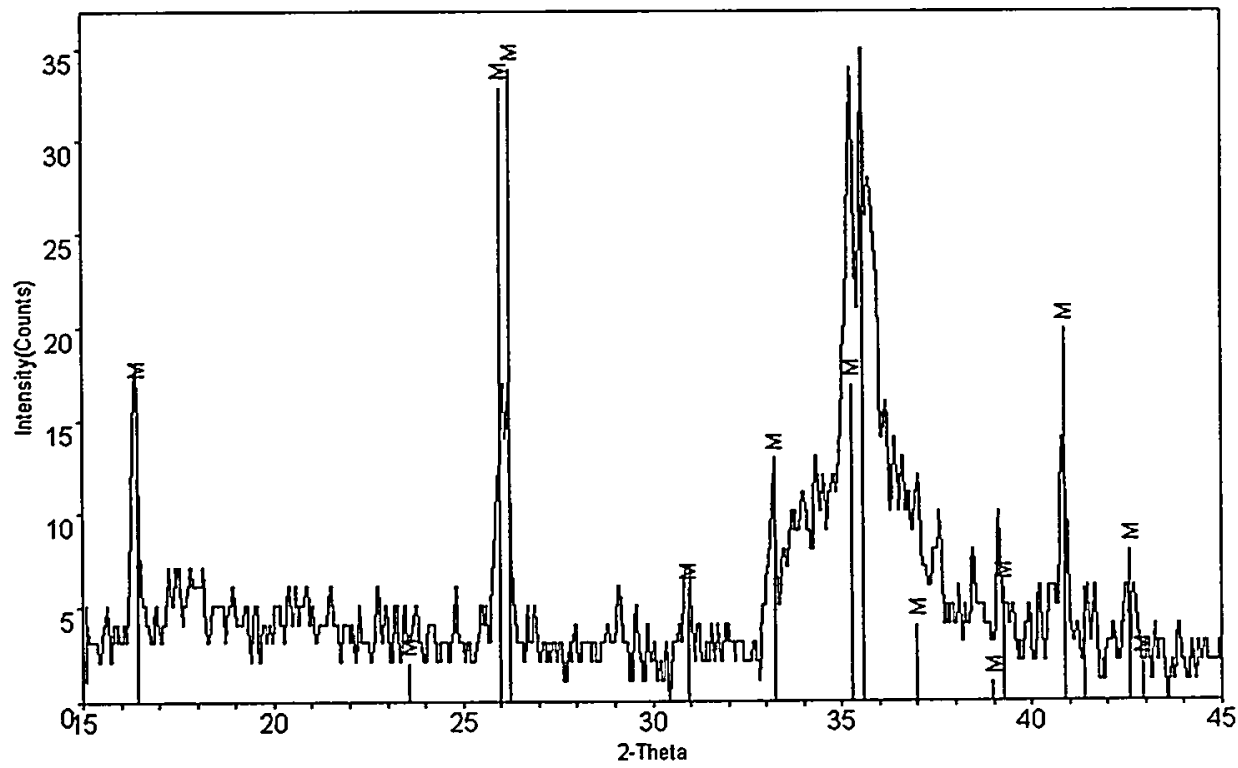

Figure 4: X-ray pattern from a mullite coated Nicalon tow. 


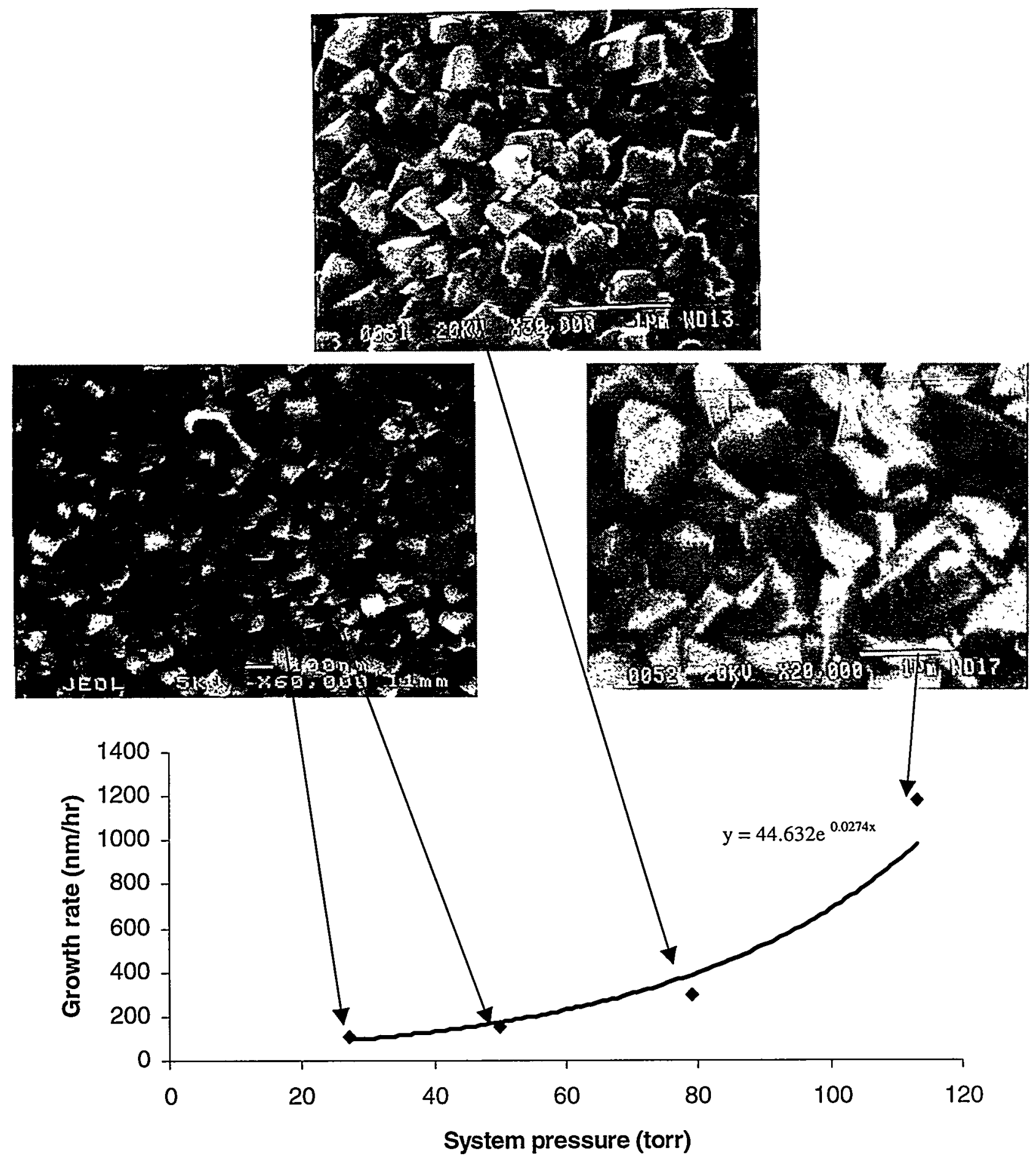

Figure 5: Effect of system pressure on growth rate and microstructure. 


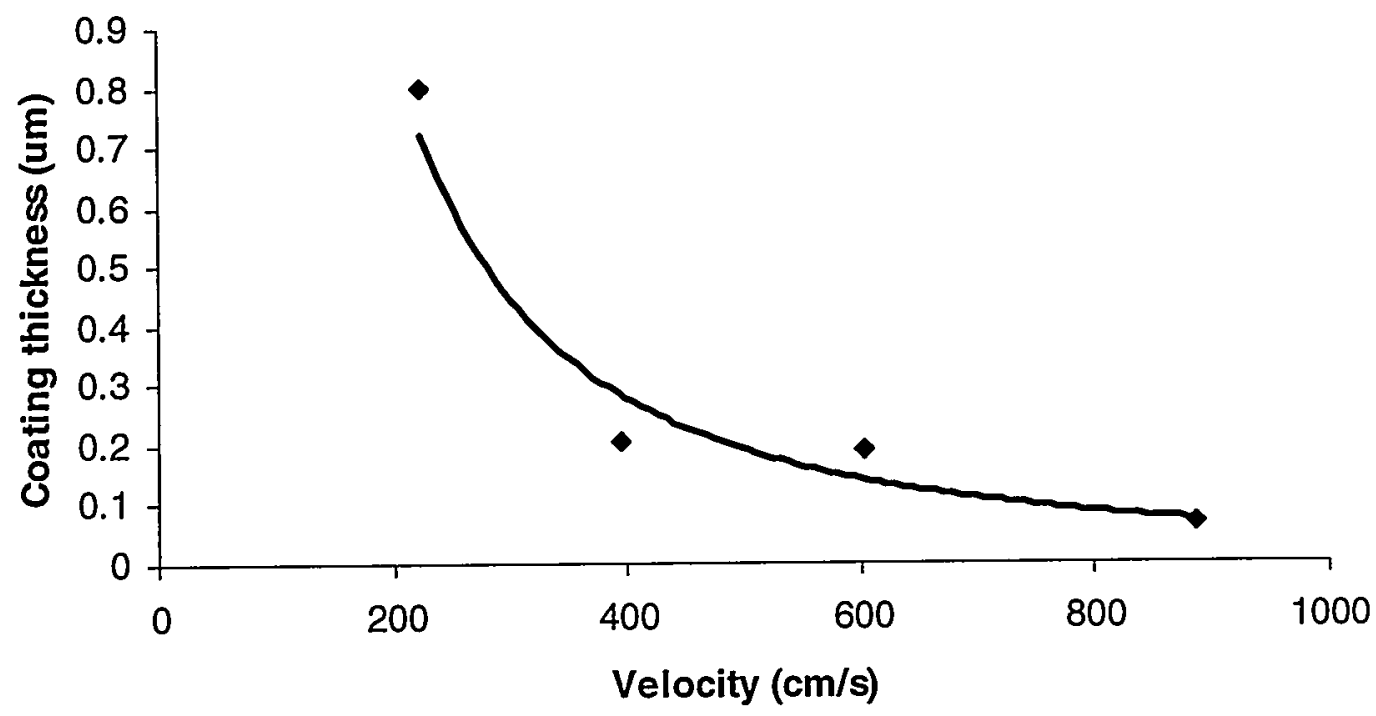

Figure 6: Coating thickness vs. input gas velocity

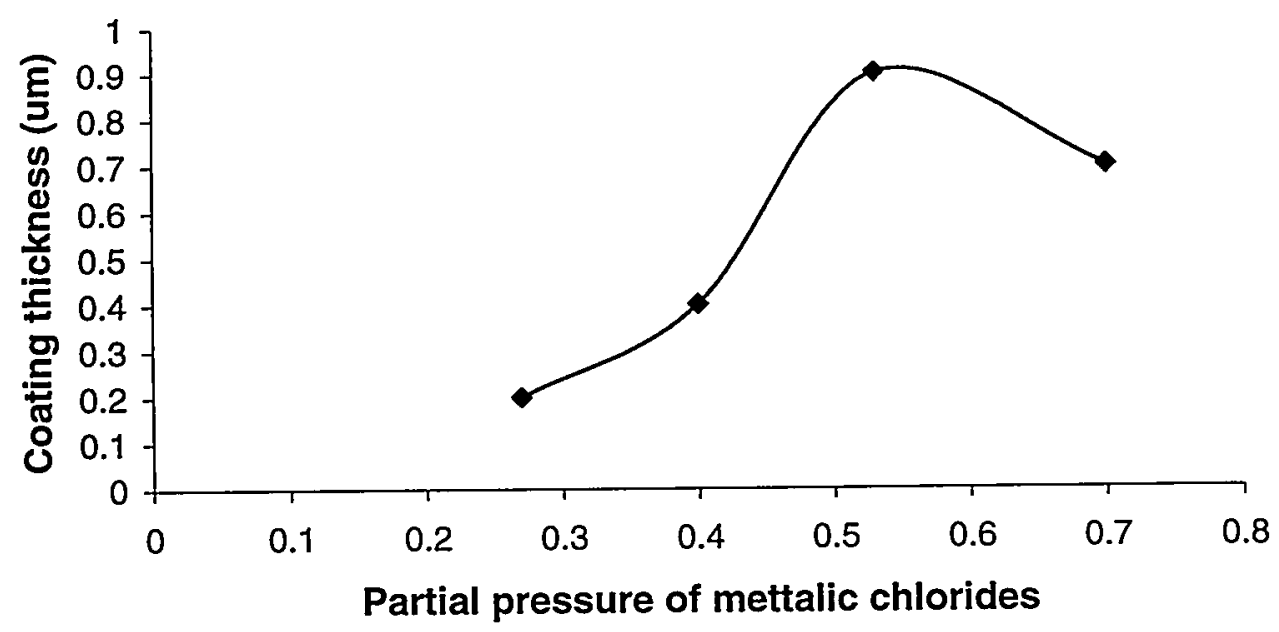

Figure 7: Coating thickness vs. partial pressure of metallic chlorides 

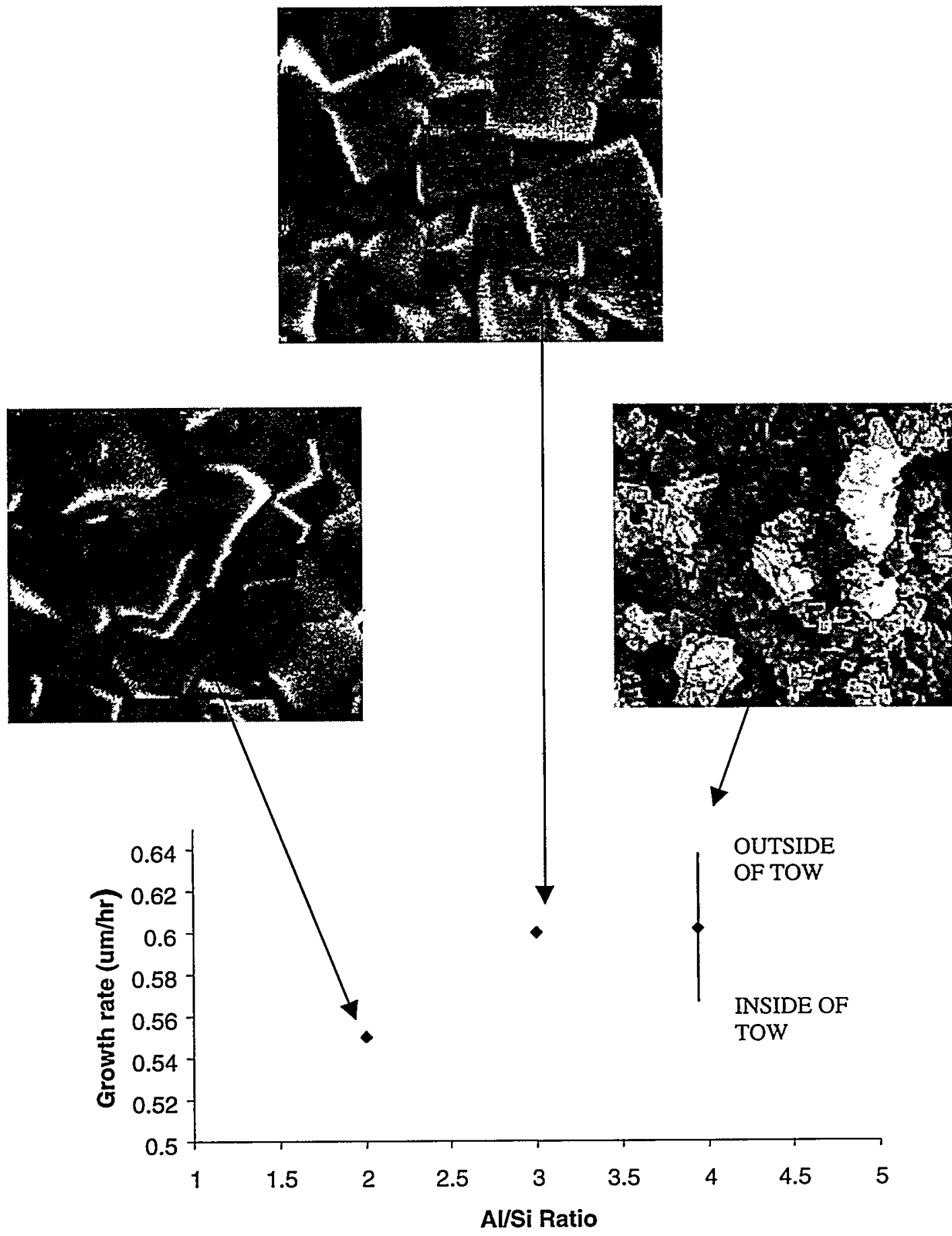

Figure 8: Effect of Al/Si ratio in the input gas at a constant partial pressure of metallic chloride. 


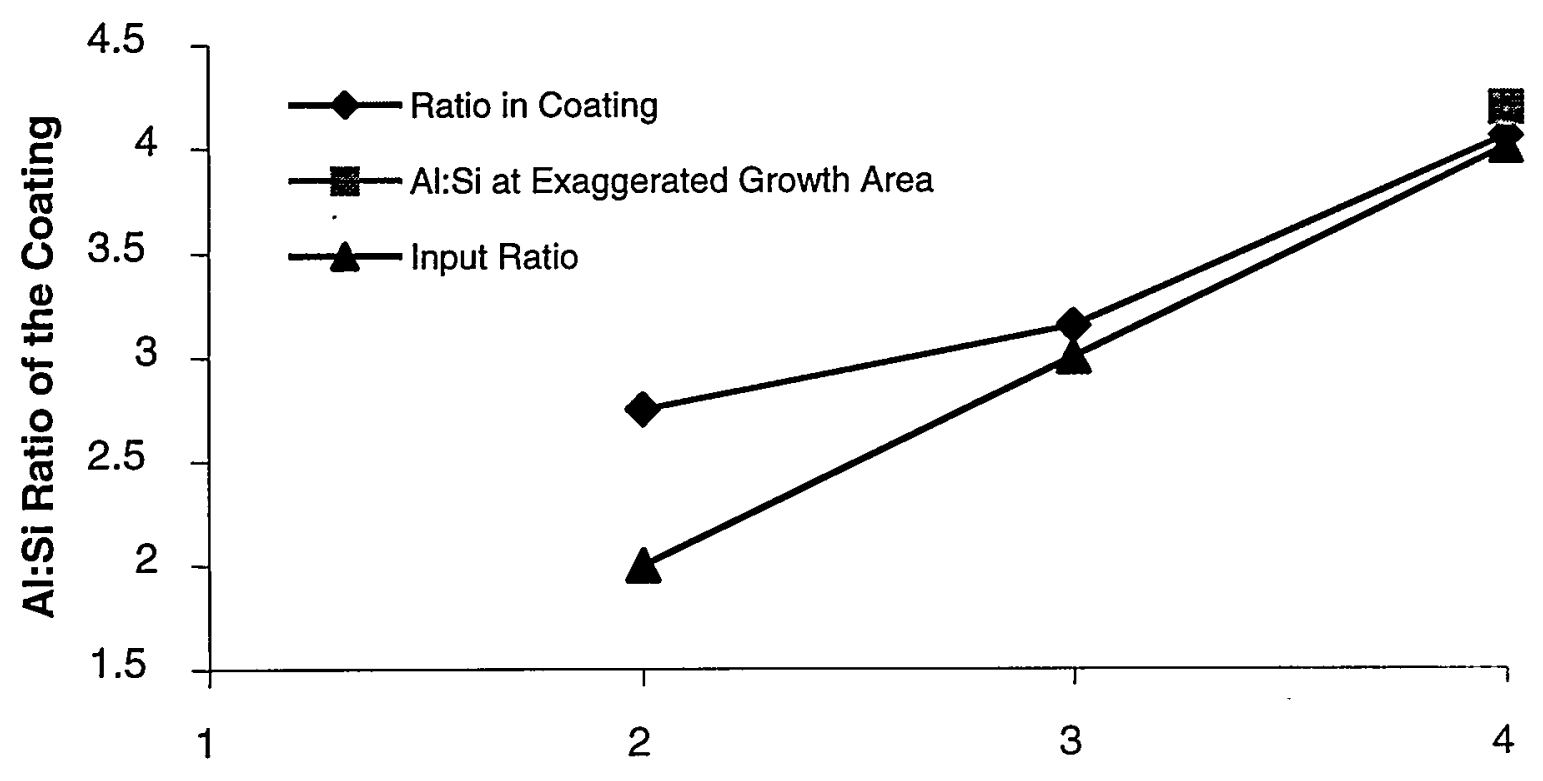

Al:Si Ratio of Input Gas

Figure 9: Plot of Al/Si ratio at the surface of the coating vs. Al/Si ratio in input gas. 


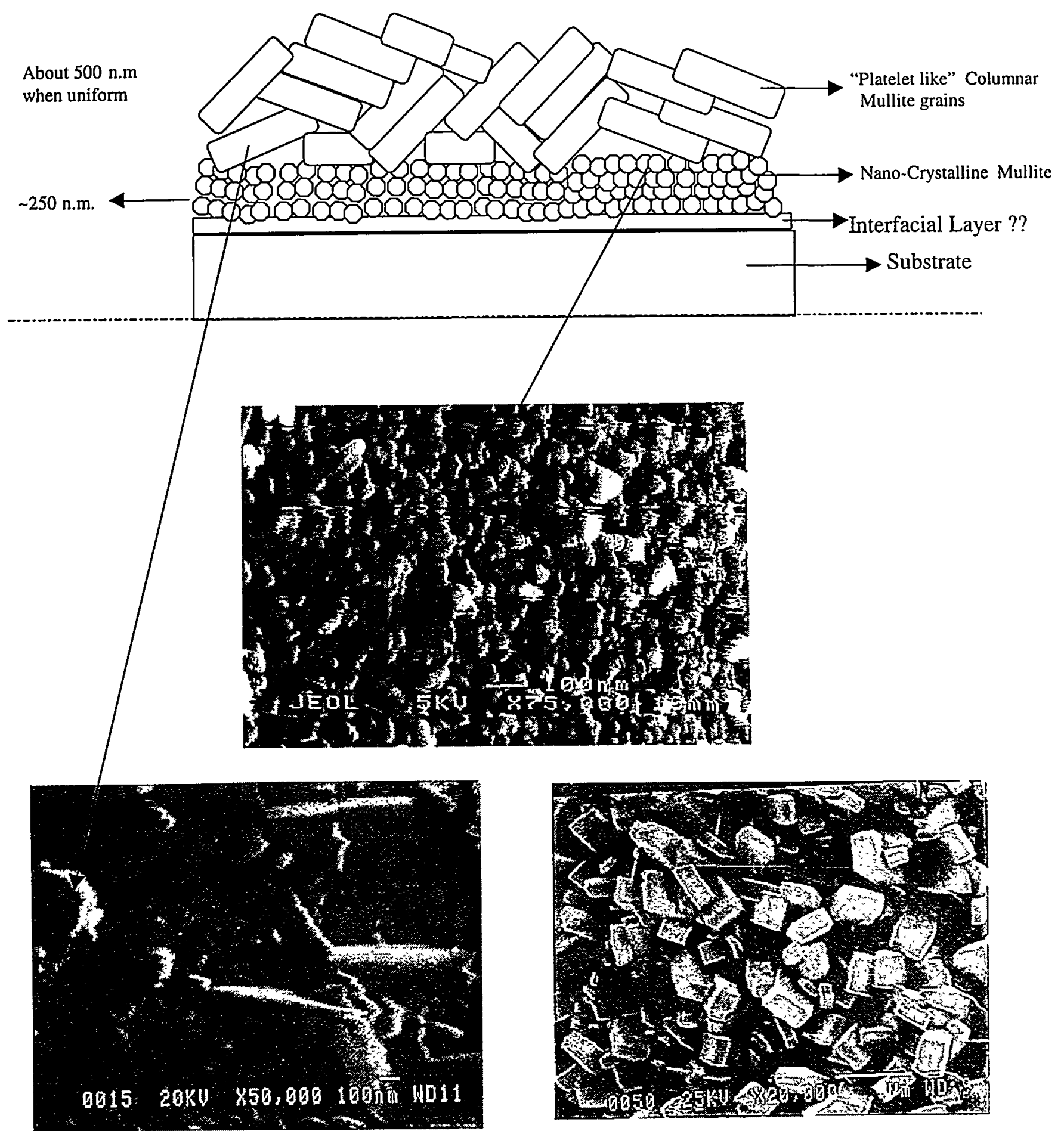

Figure 10: Structure of mullite coating on SiC fibers. 


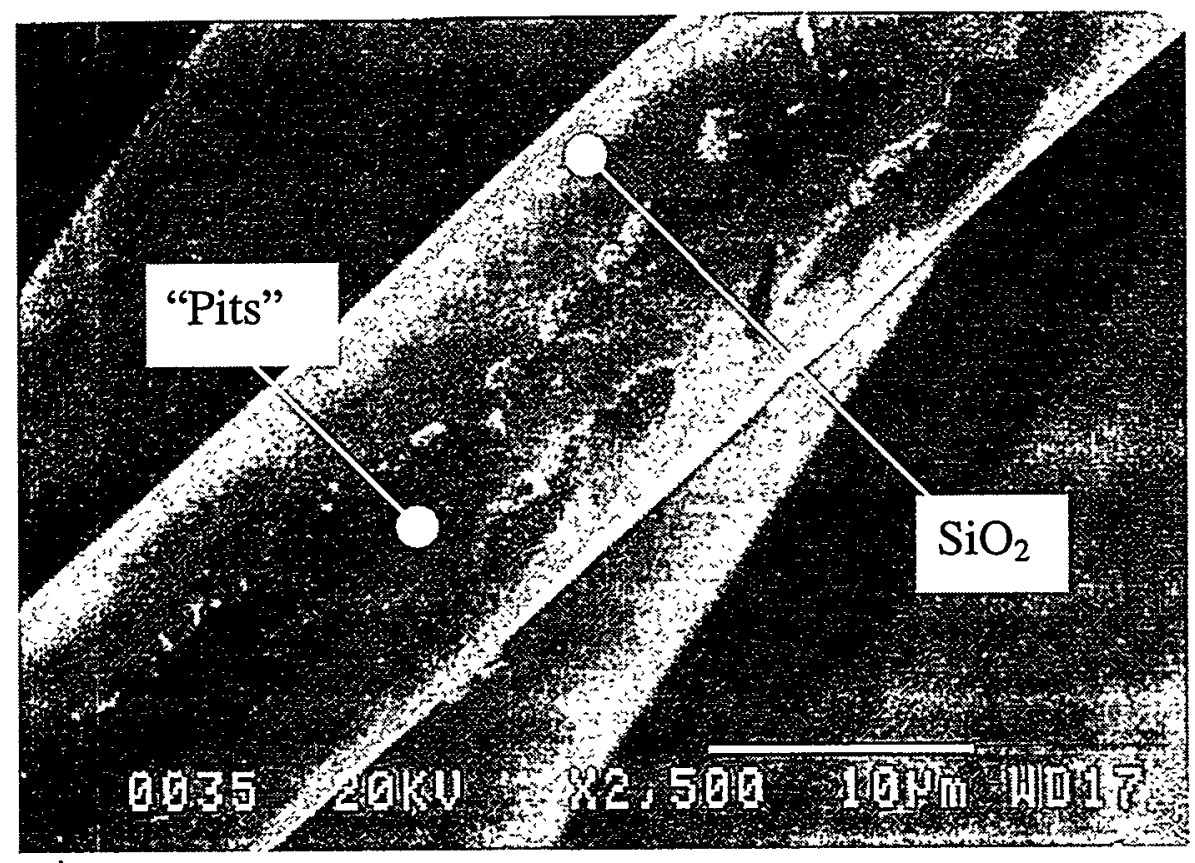

Figure 11: Surface of uncoated fibers after oxidation testing.

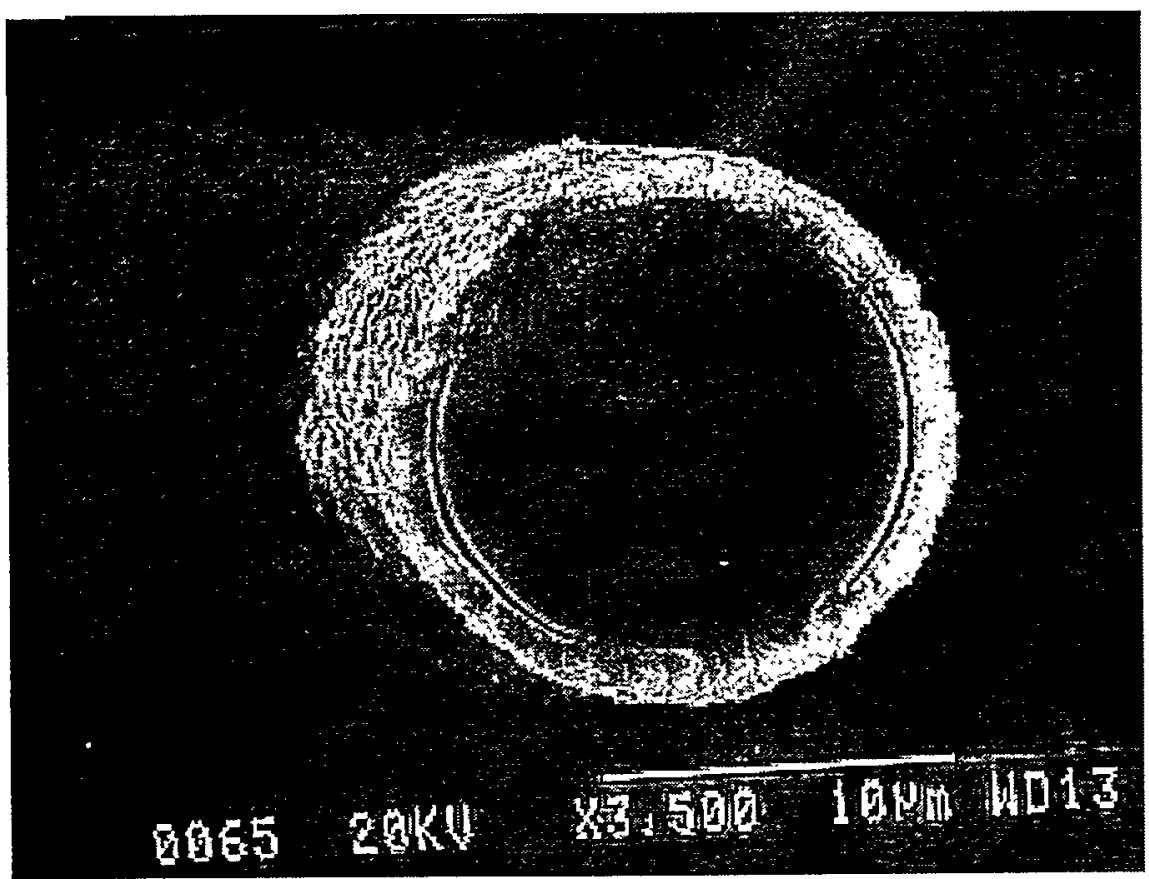

Figure 12: Uncoated end of coated fibers showed damage due to oxidation testing. 


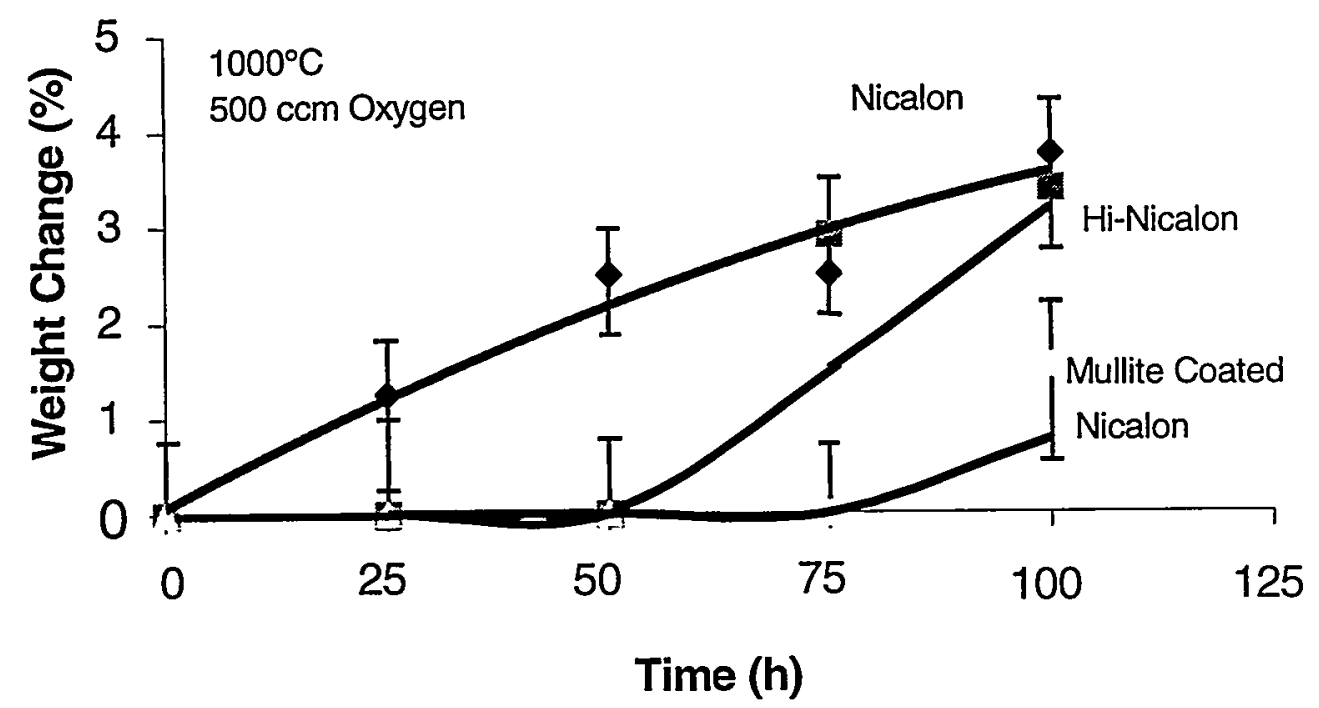

Figure 13: Performance of uncoated and coated tows during oxidation testing at $1000^{\circ} \mathrm{C}$.

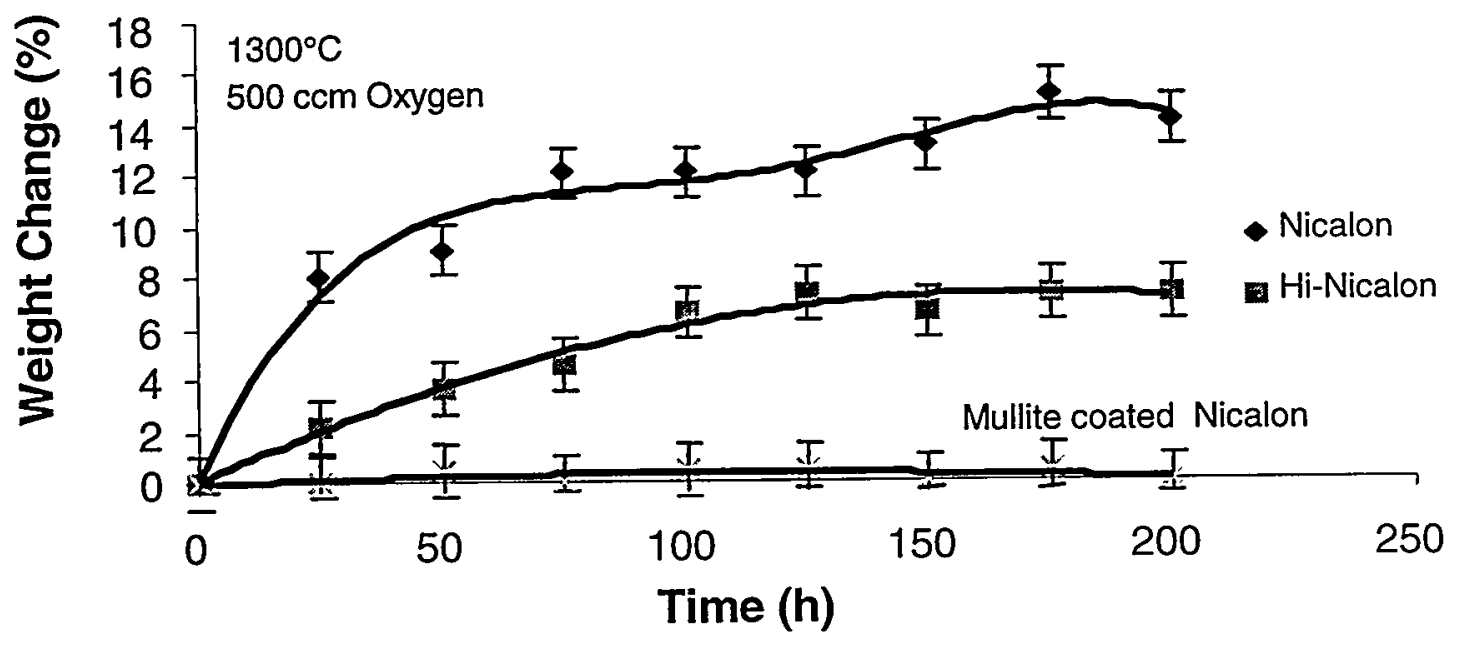

Figure 14: Weight change vs. time for uncoated and coated tows at $1300^{\circ} \mathrm{C}$. 


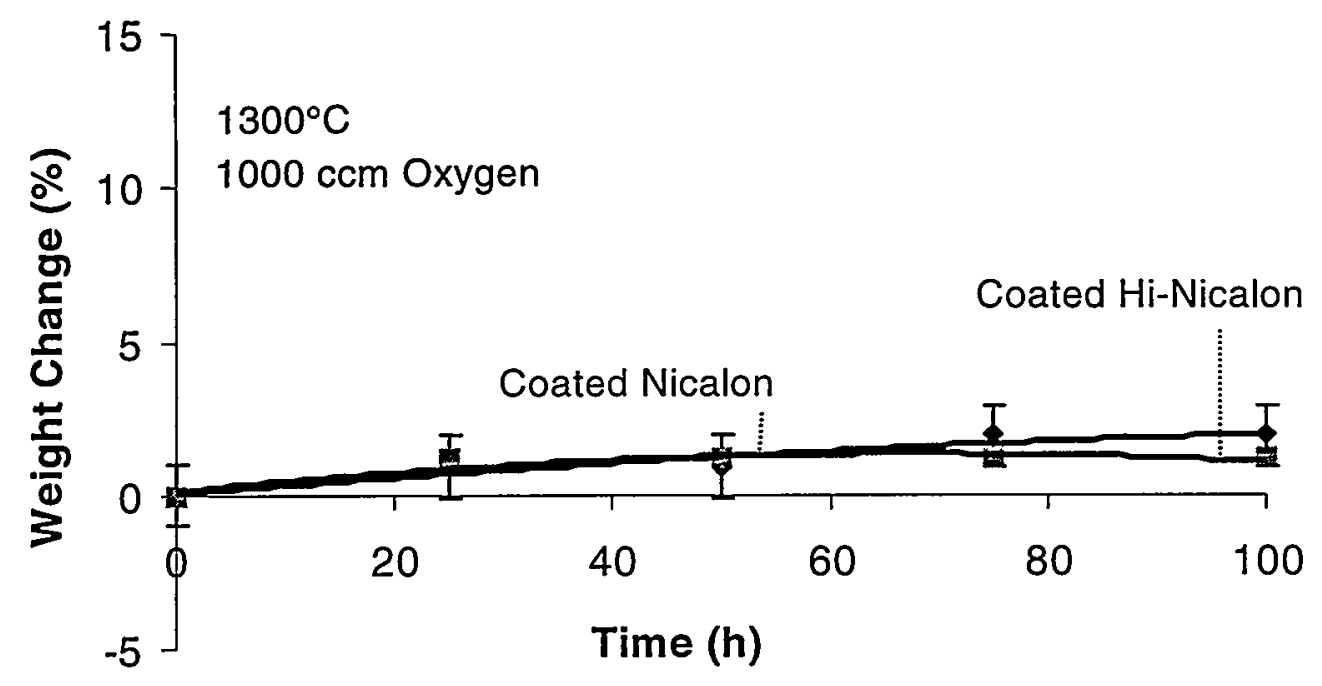

Figure 15: Comparison of performance of coated Nicalon and Hi-Nicalon.

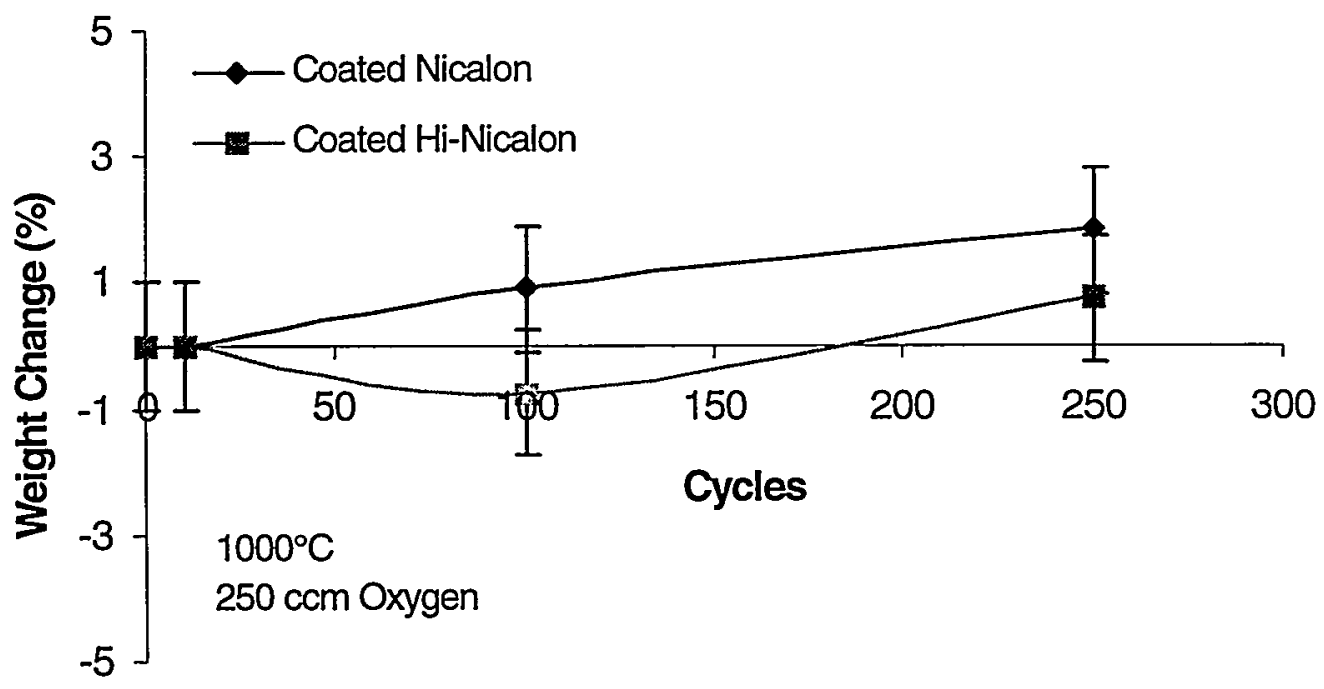

Figure 16: Weight change vs. cycles for coated Nicalon and Hi-Nicalon during cyclic oxidation testing. 

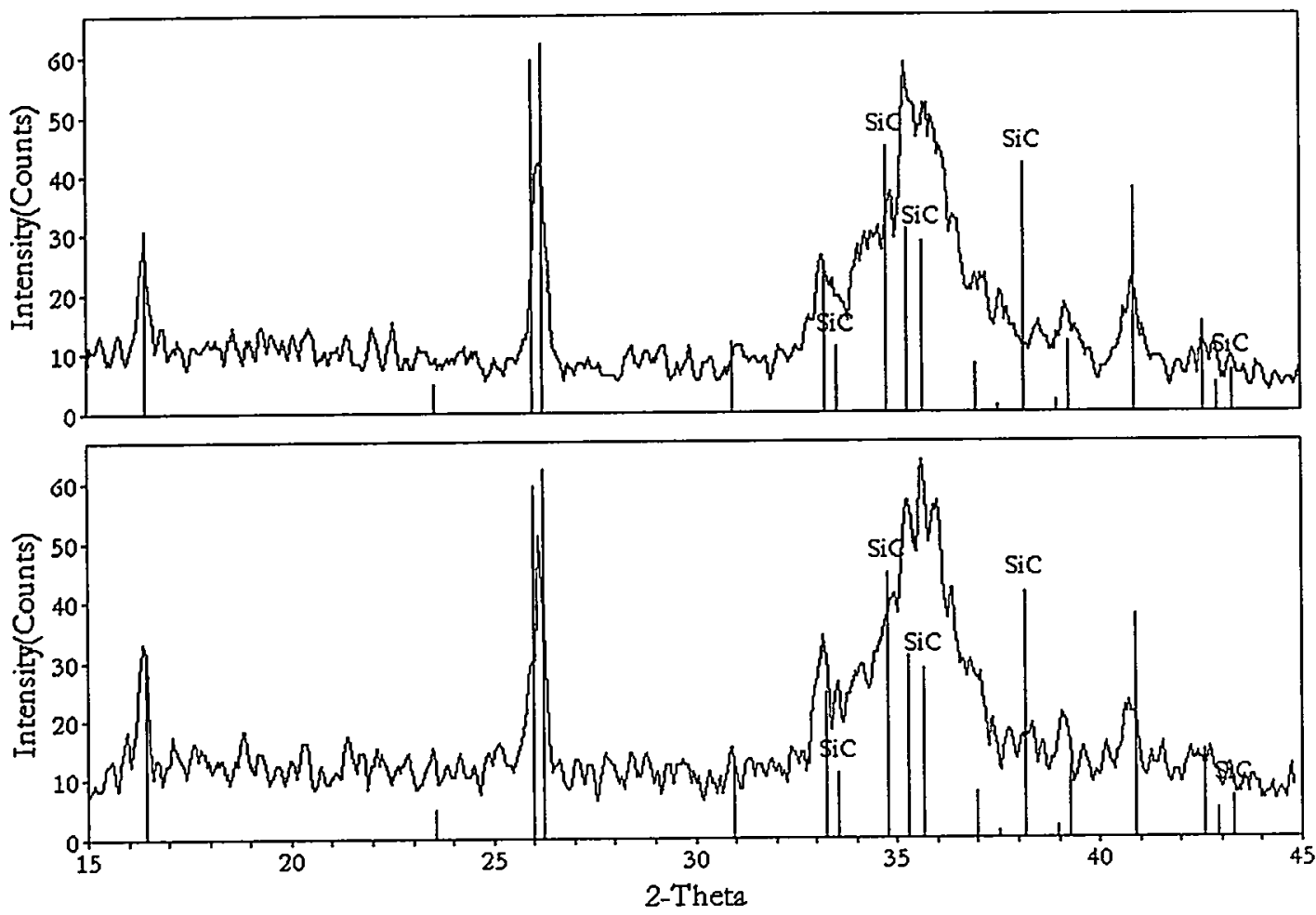

Figure 17: XRD pattern of coated Nicalon before and after cyclic oxidation testing. Un-marked peaks are from the coating.

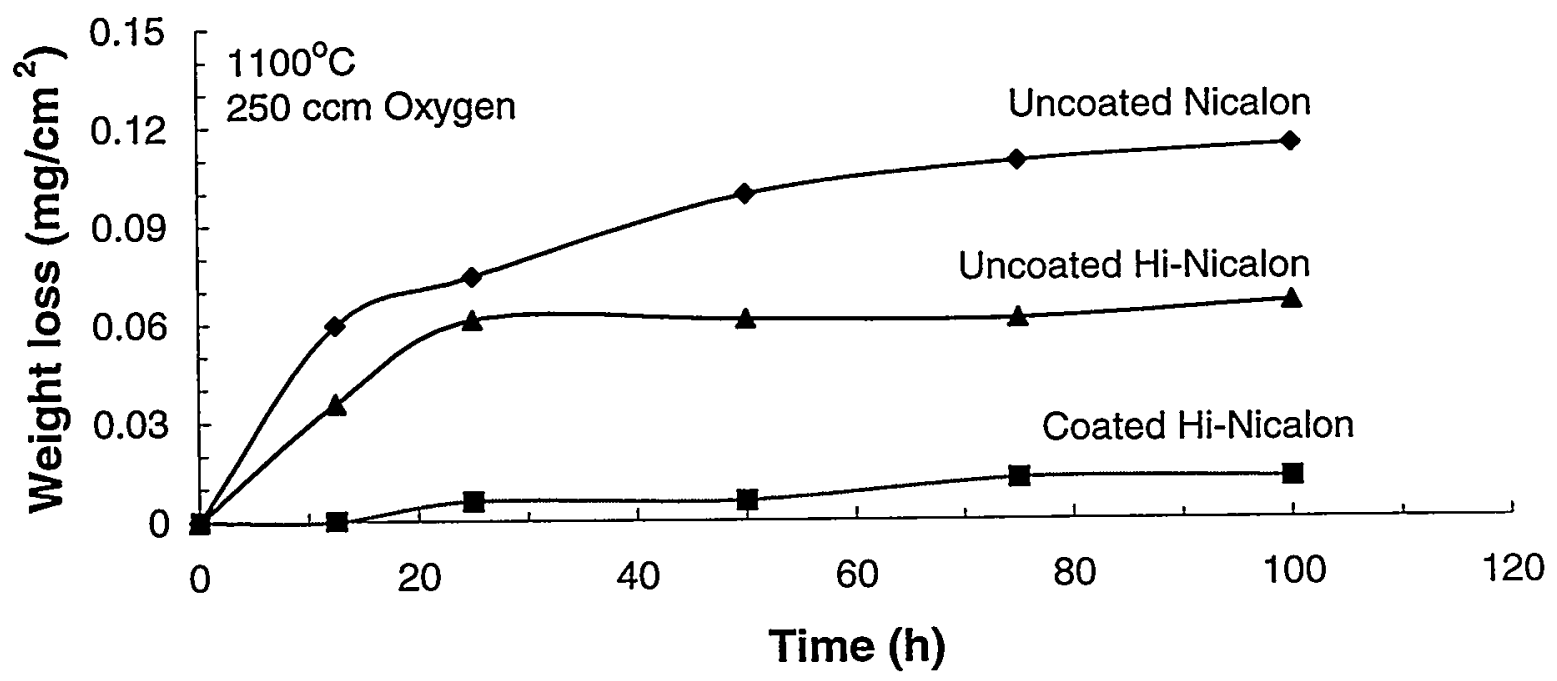

Figure 18: Weight loss vs time after hot corrosion testing. 

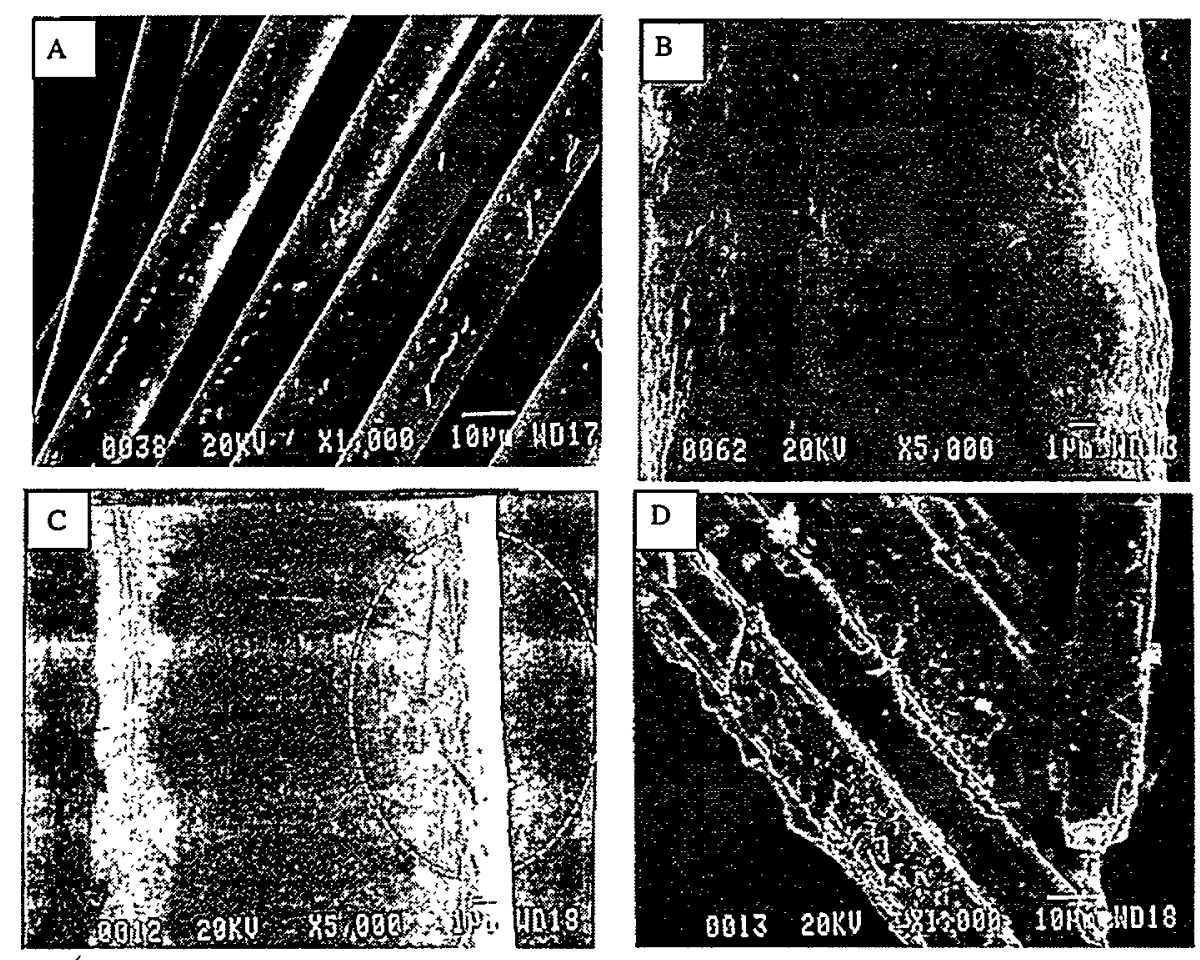

Figure 19: SEM micrographs showing A) Pitting and smooth surface, B) Bubbled surface, C) Cracked surface and D) Bridged fibers. 

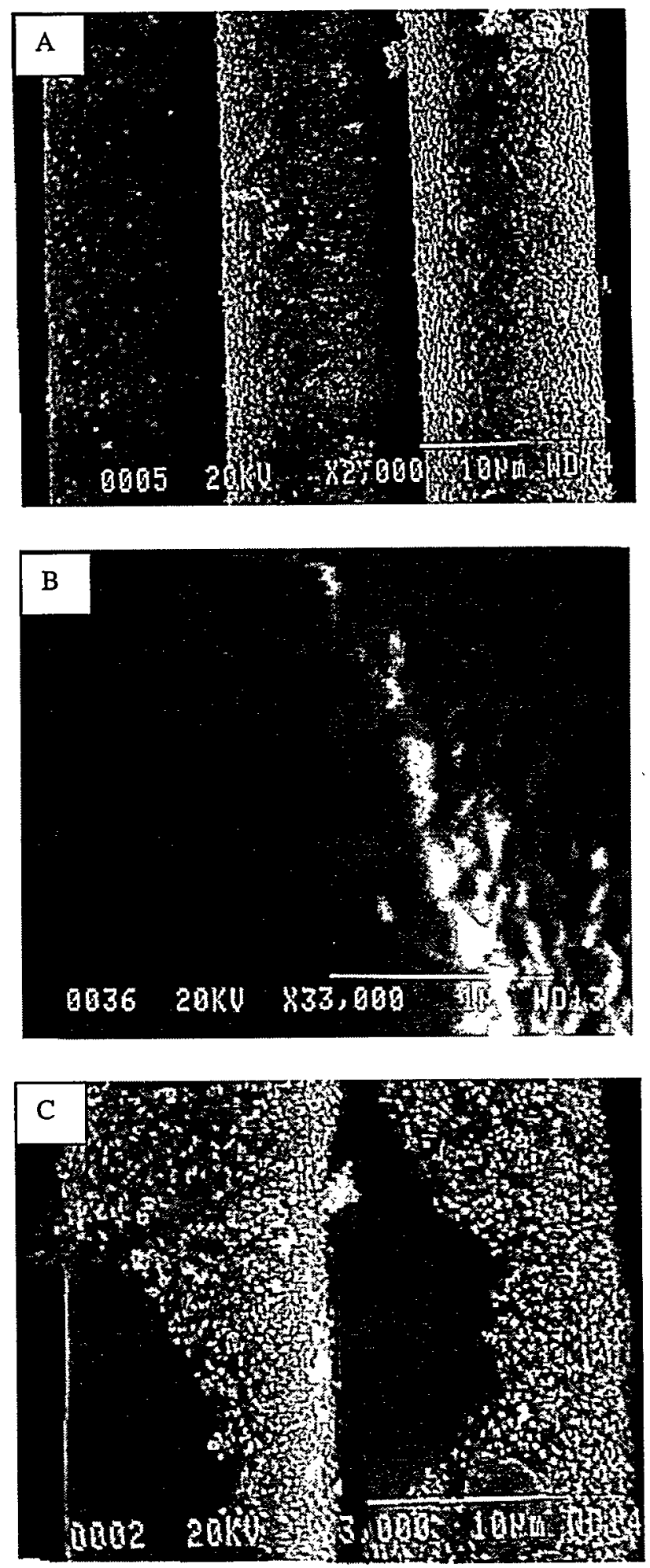

Figure 20: SEM Micrographs showing A) Undamaged coated fibers after corrosion testing B) undamaged interface and C) Few ( $<5 \%)$ damaged fibers. 


\section{CERAMIC COMPOSITES DISTRIBUTION}

3M COMPANY

Ceramic Materials Department

201-4N-01 3M Center,

St. Paul, MN 55144

M. A. Leitheiser

AIR PRODUCTS AND CHEMICALS

P.O. Box 538

Allentown, PA 18105

S. W. Dean

ALBANY RESEARCH CENTER

1450 Queen Avenue, SW

Albany, OR 97321

R. P. Walters

ALLISON GAS TURBINE DIVISION

P.O. Box 420

Indianapolis, IN 46206-0420

P. Khandelwal (Speed Code W-5)

R. A. Wenglarz (Speed Code W-16)

AMA RESEARCH \& DEVELOPMENT CENTER

5950 McIntyre Street

Golden, $\mathrm{CO} 80403$

T. B. Cox

ARGONNE NATIONAL LABORATORY

9700 S. Cass Avenue

Argonne, IL 60439

W. A. Ellingson

BABCOCK \& WILCOX

Domestic Fossil Operations

20 South Van Buren Avenue

Barberton, $\mathrm{OH} 44023$

M. Gold

BOSTON UNIVERSITY

Manufacturing Engineering

44 Cummington Street

Boston, MA 02215

V. Sarin
BRITISH COAL CORPORATION

Coal Technology Development Division

Stoke Orchard, Cheltenham

Glocestershire, England GL52 4ZG

J. Oakey

DOE

NATIONAL ENERGY TECHNOLOGY LABORATORY

3610 Collins Ferry Road

P.O. Box 880

Morgantown, WV 26507-0880

R. C. Bedick

D. C. Cicero

R. A. Dennis

N. T. Holcombe

W. J. Huber

T. J. McMahon

J. E. Notestein

DOE

NATIONAL ENERGY TECHNOLOGY LABORATORY

626 Cochrans Mill Road

P.O. Box 10940

Pittsburgh, PA 15236-0940

A. L. Baldwin

G. V. McGurl

U. Rao

L. A. Ruth

T. M. Torkos

DOE

DOE OAK RIDGE OPERATIONS

P. O. Box 2008

Building 4500N, MS 6269

Oak Ridge, TN 37831

M. H. Rawlins

DOE

OFFICE OF FOSSIL ENERGY

FE-72

19901 Germantown Road

Germantown, MD 20874-1290

F. M. Glaser 


\section{DOE}

OFFICE OF VEHICLE AND ENERGY R\&D

CE-151 Forrestal Building

Washington, DC 20585

R. B. Schulz

ELECTRIC POWER RESEARCH INSTITUTE

P.O. Box 10412

3412 Hillview Avenue

Palo Alto, CA 94303

W. T. Bakker

J. Stringer

EUROPEAN COMMUNITIES JOINT RESEARCH

CENTRE

Petten Establishment

P.O. Box 2

1755 ZG Petten

The Netherlands

$M$. Van de Voorde

LAWRENCE LIVERMORE NATIONAL LABORATORY

P.O. Box 808, L-325

Livermore, CA 94550

W. A. Steele

\section{NATIONAL MATERIALS ADVISORY BOARD}

National Research Council

2101 Constitution Avenue

Washington, DC 20418

K. M. Zwilsky

OAK RIDGE NATIONAL LABORATORY

P.O. Box 2008

Oak Ridge, TN 37831

T. M. Besmann

P. T. Carlson

J. M. Crigger ( 3 copies)

R. R. Judkins

R. A. Lowden

D. P. Stinton

OFFICE OF NAVAL RESEARCH

Code $431,800 \mathrm{~N}$. Quincy Street

Arlington, VA 22217

S. G. Fishman
REMAXCO TECHNOLOGIES, INC.

1010 Commerce Park Drive

Suite I

Oak Ridge, TN 37830

R. D. Nixdorf

SHELL DEVELOPMENT COMPANY

WTC R-1371

P.O. Box 1380

Houston, TX 77251-1380

W. C. Fort

TENNESSEE VALLEY AUTHORITY

Energy Demonstration \& Technology MR2N58A

Chattanooga, TN 37402-280 I

C. M. Huang

THE JOHNS HOPKINS UNIVERSITY

Materials Science \& Engineering

Maryland Hall

Baltimore, MD 21218

R. E. Green, Jr.

THE NORTON COMPANY

High Performance Ceramics Division

Goddard Road

Northborough, MA 01532-1545

N. Corbin

UNION CARBIDE CORPORATION

Linde Division

P.O. Box 44

175 East Park Drive

Tonawanda, NY 14151-0044

Harry Cheung

UNITED TECHNOLOGIES RESEARCH CENTER

MS 24, Silver Lane

East Hartford, CT 06108

K. M. Prewo

UNIVERSITY OF LOUISVILLE

Dept of Chemical Engineering

Speed Scientific School

Louisville, KY 40292

T. L. Starr 
UNIVERSITY OF NORTH DAKOTA

Energy and Environmental Research Center

15 North 23rd Street

Grand Forks. ND 56202

J. P. Hurley

UNIVERSITY OF WASHINGTON

Department of Materials Science and

Engineering

101 Wilson, FB-10

Seattle, WA 98195

T. G. Stoebe

VIRGINIÁ POLYTECHNIC INSTITUTE \& STATE

UNIVERSITY

Department of Materials Engineering

Blackburg, VA. 24601

K. L. Reifsnider

WESTERN RESEARCH INSTITUTE

$365 \mathrm{~N}$. 9th Street

P.O. Box 3395

University Station

Laramie, WY 82071

V. K. Sethi

WESTINGHOUSE ELECTRIC CORPORATION

Research and Development Center

1310 Beulah Road

Pittsburgh, PA 15235-5098

S. C. Singhal 